\title{
Evaluation of RNA concentration as an indicator of growth in young-of-the-year winter flounder Pseudopleuronectes americanus and tautog Tautoga onitis
}

\author{
Catherine Kuropat ${ }^{1, *}$, Renee Mercaldo-Allen ${ }^{1}$, Elaine Caldarone ${ }^{2}$, \\ Ronald Goldberg ${ }^{1}$, Beth Phelan ${ }^{3}$, Frederick Thurberg ${ }^{1}$ \\ ${ }^{1}$ National Marine Fisheries Service, Northeast Fisheries Science Center, Milford Laboratory, 212 Rogers Avenue, \\ Milford, Connecticut 06460, USA \\ ${ }^{2}$ National Marine Fisheries Service, Northeast Fisheries Science Center, Narragansett Laboratory, 28 Tarzwell Drive, \\ Narragansett, Rhode Island 02882, USA \\ ${ }^{3}$ National Marine Fisheries Service, Northeast Fisheries Science Center, James J. Howard Marine Sciences Laboratory, \\ 74 Magruder Road, Highlands, New Jersey 07732, USA
}

\begin{abstract}
White muscle tissue RNA concentration was evaluated as an indirect measure of fish growth. Young-of-the-year winter flounder Pseudopleuronectes americanus and tautog Tautoga onitis were grown in short-term caging experiments conducted during 1994 and 1995 within 3 geographically distinct estuarine systems in the NE of the USA: the Hammonasset River along the Connecticut coast of Long Island Sound, the Navesink River located in the Hudson-Raritan Bay estuary in northern New Jersey, and Great Bay-Little Egg Harbor estuary in southern New Jersey. Fish were caged in each of 5 habitat types including: eelgrass, macroalgae, unvegetated areas adjacent to eelgrass, unvegetated areas adjacent to macroalgae, and tidal marsh creeks. White muscle tissue RNA concentration ( $\mu \mathrm{g}$ per mg wet tissue wt) was measured in winter flounder and tautog recovered from the cages and compared to instantaneous growth rate measurements of these same fish. RNA concentration was significantly correlated with growth rate measured as length $(r=0.83)$ and weight $(\mathrm{r}=0.79)$ in winter flounder and length $(\mathrm{r}=0.69)$ and weight $(\mathrm{r}=0.73)$ in tautog. In most cases, estuary- and habitat-specific differences in growth rate, as determined by RNA concentration, were similar to those determined by measuring instantaneous growth. These results validate the use of RNA concentration as an indirect measure of growth in young-of-the-year winter flounder and tautog.
\end{abstract}

KEY WORDS: RNA $\cdot$ Winter flounder $\cdot$ Tautog $\cdot$ Estuary $\cdot$ Habitat

\section{INTRODUCTION}

Traditionally, somatic growth measurements obtained through caging studies have been used to assess habitat specific growth patterns in juvenile fish (Sogard 1992, Able 1999, Phelan et al. 2000). Growth

*E-mail: catherine.kuropat@noaa.gov observations of caged fish may not accurately represent growth of wild fish in these same habitats. Differences in handling procedures and measuring techniques may introduce variability to growth results. Cage designs, which exclude certain prey types, may reduce growth rates (Able 1999). Caged fish, unable to avoid poor water quality, may experience reduced growth when stressed by unfavorable environmental conditions. Furthermore, caging studies are both time- 
consuming and labor-intensive and require an extensive field effort. These factors suggest that caging may not represent the most efficient and accurate means of assessing growth.

Biochemical techniques such as nucleic acid analyses have proven useful in studying the recent growth of young fish in response to environmental variability (Buckley et al. 1999). Ribonucleic acid (RNA) concentration has been used to indicate and predict protein synthesis rate, relative condition (Bulow 1987), and instantaneous growth rate (Mathers et al. 1992) in many species of juvenile fish (Goolish et al. 1984, Balstrop et al. 1991, Varnavskiy et al. 1991, Mathers et al. 1992, 1993, Foster et al. 1993, Wang et al. 1993, Carter et al. 1998). Nucleic acid analyses offer several advantages. The RNA methodology uses a small sample of white muscle tissue and reflects growth 1 to $3 \mathrm{~d}$ prior to sampling. This procedure is not subject to the errors implicit in repeated length and/or weight measurements of slow-growing fish and can be used in studies where no direct measure of growth rate is available. Further, RNA analysis can be used when caging or tagging and recapture of animals is impractical or impossible.

This study uses caging experiments to evaluate white muscle tissue RNA concentration as an indicator of short-term instantaneous growth rate for young-ofthe-year winter flounder Pseudopleuronectes americanus and tautog Tautoga onitis. The suitability of the RNA-growth method and its applications as a relative measure of habitat quality is also addressed. This study is among the first to evaluate field growth of caged fish using both RNA concentration and instantaneous growth measurements.

\section{MATERIALS AND METHODS}

Study sites. Caging studies were conducted in 5 different habitat types within 3 geographically distinct estuaries in the NE of the USA during 1994 and 1995. Study sites included the Hammonasset River, along the Connecticut coast, part of the Long Island Sound estuarine system; the Navesink River in northern New Jersey, part of the Hudson-Raritan Bay estuarine system; and the Great Bay/Little Egg Harbor estuary in southern New Jersey. Fish were deployed into replicate areas representing 5 habitat types: eelgrass (EG) beds (Zostera marina), bottom colonized by drifting or attached macroalgae (MA) (primarily Ulva lactuca), unvegetated areas adjacent to eelgrass (UEG) and unvegetated areas adjacent to macroalgae (UMA), and tidal marsh creeks (MC). Drifting vegetation in the macroalgal habitats was ephemeral, in contrast to the more permanent eelgrass beds, therefore macroalgae was added to the appropriate cages as described in Phelan et al. (2000).

Multiple experimental runs, 9 to $11 \mathrm{~d}$ in duration, were conducted during June and July for winter flounder and August to September for tautog over the 2-yr period, corresponding with settlement of young juve-

Table 1. Field experiment characteristics for winter flounder Pseudopleuronectes americanus during 1994 and 1995

\begin{tabular}{|c|c|c|c|c|c|c|c|}
\hline \multirow[t]{2}{*}{ Estuary } & \multirow[t]{2}{*}{ Year } & \multirow{2}{*}{$\begin{array}{c}\text { Start of } \\
\text { experimental } \\
\text { run }\end{array}$} & \multirow{2}{*}{$\begin{array}{l}\text { Duration of } \\
\text { experiment } \\
\text { (d) }\end{array}$} & \multirow{2}{*}{$\begin{array}{l}\text { Fish } \\
\text { collection } \\
\text { sites }\end{array}$} & \multirow{2}{*}{$\begin{array}{l}\text { Number of } \\
\text { fish analyzed } \\
\text { for RNA }\end{array}$} & \multicolumn{2}{|c|}{$\begin{array}{c}\text { Initial size } \\
\text { mean and (range) }\end{array}$} \\
\hline & & & & & & Std. length (mm) & Weight (g) \\
\hline \multirow[t]{2}{*}{ Hammonasset } & \multirow[t]{2}{*}{1994} & June 27 (Expt 1) & 10 & $\begin{array}{l}\text { New Haven } \\
\text { Harbor }\end{array}$ & 15 & $\begin{array}{c}29.5 \\
(24.4-34.6)\end{array}$ & $\begin{array}{c}0.47 \\
(0.29-0.79)\end{array}$ \\
\hline & & July 26 (Expt 3) & 10 & $\begin{array}{l}\text { New Haven } \\
\text { Harbor }\end{array}$ & 52 & $\begin{array}{c}41.5 \\
(31.0-50.0)\end{array}$ & $\begin{array}{c}1.34 \\
(0.53-3.42)\end{array}$ \\
\hline \multirow[t]{2}{*}{ Navesink } & \multirow[t]{2}{*}{1994} & June 7 (Expt 1) & 10 & Navesink & 51 & $\begin{array}{c}25.0 \\
(19.0-31.2)\end{array}$ & $\begin{array}{c}0.25 \\
(0.10-0.45)\end{array}$ \\
\hline & & July 5 (Expt 3) & 10 & Navesink & 41 & $\begin{array}{c}32.4 \\
(26.2-41.2)\end{array}$ & $\begin{array}{c}0.50 \\
(0.21-1.13)\end{array}$ \\
\hline \multirow[t]{2}{*}{$\begin{array}{l}\text { Great Bay/ } \\
\text { Little Egg Harbor }\end{array}$} & \multirow[t]{2}{*}{1994} & June 3 (Expt 1) & 10 & $\begin{array}{l}\text { Great Bay/ } \\
\text { Little Egg Harbor }\end{array}$ & 51 & $\begin{array}{c}16.0 \\
(12.0-21.9)\end{array}$ & - \\
\hline & & June 28 (Expt 3) & 9 & $\begin{array}{l}\text { Great Bay/ } \\
\text { Little Egg Harbor }\end{array}$ & 60 & $\begin{array}{c}35.8 \\
(23.7-60.4)\end{array}$ & $\begin{array}{c}0.99 \\
(0.20-3.84)\end{array}$ \\
\hline Hammonasset & 1995 & June 26 (Expt 2) & 10 & $\begin{array}{l}\text { New Haven } \\
\text { Harbor }\end{array}$ & 76 & $\begin{array}{c}45.9 \\
(33.3-55.6)\end{array}$ & $\begin{array}{c}1.62 \\
(0.60-2.67)\end{array}$ \\
\hline Navesink & 1995 & June 9 (Expt 2) & 10 & Navesink & 52 & $\begin{array}{c}26.7 \\
(18.7-33.2)\end{array}$ & $\begin{array}{c}0.32 \\
(0.10-0.56)\end{array}$ \\
\hline $\begin{array}{l}\text { Great Bay/ } \\
\text { Little Egg Harbor }\end{array}$ & 1995 & June 12 (Expt 2) & 10 & $\begin{array}{l}\text { Great Bay/ } \\
\text { Little Egg Harbor }\end{array}$ & 50 & $\begin{array}{c}32.1 \\
(23.1-42.8)\end{array}$ & $\begin{array}{c}0.58 \\
(0.18-1.33)\end{array}$ \\
\hline
\end{tabular}


Table 2. Field experiment characteristics for tautog Tautoga onitis during 1994 and 1995

\begin{tabular}{|c|c|c|c|c|c|c|c|}
\hline \multirow[t]{2}{*}{ Estuary } & \multirow[t]{2}{*}{ Year } & \multirow{2}{*}{$\begin{array}{c}\text { Start of } \\
\text { experimental } \\
\text { run }\end{array}$} & \multirow{2}{*}{$\begin{array}{l}\text { Duration of } \\
\text { experiment } \\
\text { (d) }\end{array}$} & \multirow{2}{*}{$\begin{array}{l}\text { Fish } \\
\text { collection } \\
\text { sites }\end{array}$} & \multirow{2}{*}{$\begin{array}{l}\text { Number of } \\
\text { fish analyzed } \\
\text { for RNA }\end{array}$} & \multicolumn{2}{|c|}{$\begin{array}{c}\text { Initial size } \\
\text { mean and (range) }\end{array}$} \\
\hline & & & & & & Total length (mm) & Weight (g) \\
\hline \multirow[t]{3}{*}{ Hammonasset } & \multirow[t]{3}{*}{1994} & August 26 (Expt 1) & 11 & $\begin{array}{l}\text { New Haven } \\
\text { Harbor }\end{array}$ & 32 & $\begin{array}{c}37.0 \\
(27.8-51.4)\end{array}$ & $\begin{array}{c}0.68 \\
(0.27-1.86)\end{array}$ \\
\hline & & September 13 (Expt 2) & 11 & $\begin{array}{l}\text { New Haven } \\
\text { Harbor }\end{array}$ & 18 & $\begin{array}{c}43.3 \\
(36.4-66.6)\end{array}$ & $\begin{array}{c}1.16 \\
(0.55-4.23)\end{array}$ \\
\hline & & September 24 (Expt 3) & 9 & $\begin{array}{l}\text { New Haven } \\
\text { Harbor }\end{array}$ & 26 & $\begin{array}{c}48.0 \\
(34.2-64.9)\end{array}$ & $\begin{array}{c}1.48 \\
(0.48-3.29)\end{array}$ \\
\hline \multirow[t]{3}{*}{ Navesink } & \multirow[t]{3}{*}{1994} & July 22 (Expt 1) & 10 & Navesink & 35 & $\begin{array}{c}32.3 \\
(27.2-38.5)\end{array}$ & $\begin{array}{c}0.38 \\
(0.21-0.70)\end{array}$ \\
\hline & & August 5 (Expt 2) & 10 & Navesink & 59 & $\begin{array}{c}36.2 \\
(24.6-46.8)\end{array}$ & $\begin{array}{c}0.60 \\
(0.16-1.28)\end{array}$ \\
\hline & & August 19 (Expt 3) & 10 & Navesink & 45 & $\begin{array}{c}45.3 \\
(30.9-54.2)\end{array}$ & $\begin{array}{c}1.22 \\
(0.34-2.16)\end{array}$ \\
\hline \multirow[t]{2}{*}{ Hammonasset } & \multirow[t]{2}{*}{1995} & August 4 (Expt 1) & 10 & $\begin{array}{l}\text { New Haven } \\
\text { Harbor }\end{array}$ & 79 & $\begin{array}{c}43.1 \\
(26.0-60.3)\end{array}$ & $\begin{array}{c}1.12 \\
(0.21-3.03)\end{array}$ \\
\hline & & August 17 (Expt 2) & 11 & $\begin{array}{l}\text { New Haven } \\
\text { Harbor }\end{array}$ & 67 & $\begin{array}{c}49.3 \\
(30.2-67.1)\end{array}$ & $\begin{array}{c}1.80 \\
(0.37-4.50)\end{array}$ \\
\hline \multirow[t]{2}{*}{ Navesink } & \multirow[t]{2}{*}{1995} & August 11 (Expt 1) & 10 & $\begin{array}{l}\text { New Haven } \\
\text { Harbor }\end{array}$ & 46 & $\begin{array}{c}42.5 \\
(30.7-55.3)\end{array}$ & $\begin{array}{c}1.02 \\
(0.32-2.19)\end{array}$ \\
\hline & & August 25 (Expt 2) & 10 & $\begin{array}{l}\text { New Haven } \\
\text { Harbor }\end{array}$ & 50 & $\begin{array}{c}43.8 \\
(30.4-68.4)\end{array}$ & $\begin{array}{c}1.12 \\
(0.31-4.21)\end{array}$ \\
\hline \multirow[t]{2}{*}{$\begin{array}{l}\text { Great Bay/ } \\
\text { Little Egg Harbor }\end{array}$} & \multirow[t]{2}{*}{1995} & August 11 (Expt 1) & 11 & $\begin{array}{l}\text { New Haven } \\
\text { Harbor }\end{array}$ & 53 & $\begin{array}{c}40.5 \\
(26.1-60.5)\end{array}$ & $\begin{array}{c}0.85 \\
(0.13-2.64)\end{array}$ \\
\hline & & August 25 (Expt 2) & 11 & $\begin{array}{l}\text { New Haven } \\
\text { Harbor }\end{array}$ & 45 & $\begin{array}{c}42.1 \\
(23.9-59.0)\end{array}$ & $\begin{array}{c}0.89 \\
(0.14-2.21)\end{array}$ \\
\hline
\end{tabular}

niles in these estuaries (Tables 1 \& 2). Additional details concerning each estuary and the experimental sites are provided elsewhere (Goldberg et al. 1993, in press, Phelan et al. 2000).

Collection, maintenance and deployment of experimental animals. Experimental design and fish handling techniques are detailed in Phelan et al. (2000). Briefly, experimental animals, collected by beach seine or beam trawl, were held in the laboratory and fed frozen brine shrimp daily for up to $3 \mathrm{~d}$ prior to caging. Each fish was marked for individual identification by subcutaneous injections of a nontoxic fluorescent material (Visible Implant Fluorescent Elastomer ${ }^{1}$ ). Standard length (SL) in winter flounder and total length (TL) in tautog were measured with calipers to the nearest $\mathrm{mm}$. Fish were blotted, weighed to the nearest $0.01 \mathrm{~g}$, and tagged. Groups of 3 fish were placed in $0.95 \mathrm{l}$ jars for a 6 to $24 \mathrm{~h}$ recovery period. Each jar of 3 fish was then randomly assigned to each cage and 3 cages were deployed per replicate site. After each 9 to $11 \mathrm{~d}$ experimental run, fish were recovered from the cages and returned to the laboratory,

${ }^{1}$ Mention of trade names does not imply endorsement by the NMFS where the blotted wet weight and length of each fish was determined. Fish from selected experimental runs were then frozen whole on dry ice, transported to the Milford Laboratory and stored at $-80^{\circ} \mathrm{C}$, prior to biochemical analysis.

Laboratory methodology. Frozen fish were dissected on a tray set on ice. Due to small fish size, white muscle tissue samples consisted of the entire dorsal fillet for winter flounder and the entire fillet from 1 side for tautog. Dissecting tools were rinsed with deionized water between dissections to avoid contamination. Each tissue sample was weighed to the nearest $0.001 \mathrm{~g}$ and placed in a test tube in an ice slurry bath. The tissue was homogenized in ice-cold distilled water using a Janke and Kunkel Ultra-Turrax ${ }^{1}$ tissue homogenizer. Replicate aliquots were frozen for RNA analysis within $48 \mathrm{~h}$.

Muscle tissue samples were analyzed using a modification of the Schmidt-Thannhauser method according to the procedures of Buckley \& Bulow (1987), with the following modification based on Buckley \& Caldarone (1988): muscle samples were hydrolyzed with $2.24 \mathrm{ml}$ of $0.3 \mathrm{~N} \mathrm{KOH}$ and the hydrolizate acidified with $1.0 \mathrm{ml}$ of $1.32 \mathrm{~N} \mathrm{HClO}_{4}$. The increased volume of base gave improved recovery of RNA. 
The resulting supernatant containing the RNA was read at a wavelength of $260 \mathrm{~nm}$ using a Ciba-Corning Gilford Response Spectrophotometer ${ }^{1}$. RNA concentration, expressed as $\mu g$ RNA per mg wet tissue, was calculated from the absorbance using the nucleotide extinction coefficient of 0.03 . As a quality control measure, a large quantity of muscle tissue was homogenized and frozen in $0.2 \mathrm{~g}$ aliquots. One control sample was processed each day along with the tissue samples to verify the accuracy of the run.

Calculations and statistical analyses. Growth of caged winter flounder and tautog was calculated as a daily $\left(\mathrm{d}^{-1}\right)$ instantaneous growth rate $(G)$ using the formula :

$$
G=\ln \left(m_{1} / m_{0}\right) / t
$$

Where $m_{0}$ and $m_{1}$ are the initial and final standard length (winter flounder) or total length (tautog) in $\mathrm{mm}$ or weight in $g$ and $t$ is the duration of the experiment in d. The complete instantaneous growth data set is presented in Phelan et al. (2000). For this analysis, a data subset (Tables $1 \&$ 2) was created consisting of selected experimental runs during which both RNA concentration and instantaneous growth measurements were known for each fish. Mean values for RNA concentration and instantaneous growth rate were determined for each group of fish in a cage and these cage means were used for all computations. A Pearson Product Moment Correlation was used to test the strength of the relationship between RNA concentration and daily instantaneous growth for each species using length and weight. The residuals from regressing RNA concentration on instantaneous growth were also examined.

Two separate analysis of variance models (ANCOVA) were conducted on the cage means of each species to assess the influence of estuary, habitat, and experimental run on each of the 2 growth indices. RNA concentration ( $\mu \mathrm{g}$ per mg wet tissue wt) was used as the dependent variable in one model and instantaneous growth rate $(G)$, expressed as standard length in winter floun$\operatorname{der}\left(G_{\mathrm{SL}}\right)$ and as wet wt in tautog $\left(G_{\mathrm{WT}}\right)$, served as the dependent variable in the other, as these measures correlated most significantly with RNA concentration. Initial length or weight was used as a covariate. The independent variables for each model included year, estuary, habitat nested in estuary, experimental run nested in year and estuary, and replicate as a random effect nested in year, estuary, habitat, and experimental run. A type III sums of squares analysis was used. Independent effects that were not significant $(p>0.05)$ were dropped and the models rerun. Post-hoc tests consisted of multiple pairwise comparisons of least square means (lsmeans) from significant effects $(p<0.05)$. Findings from these analyses were compared to determine how well RNA concentration corresponded to daily instantaneous growth results.

\section{RESULTS}

\section{Winter flounder}

The correlation between RNA concentration and instantaneous growth rate in winter flounder was highly significant ( $p<0.0001$ ), as measured by both standard length $(r=0.83)$ and weight $(r=0.79)$ for both study years combined (Fig. 1a,b). Residuals from regressing RNA concentration on growth were randomly distributed when plotted against RNA. When the residuals were plotted against initial standard length, the observed growth of the smallest fish $(<20 \mathrm{~mm})$ was higher than predicted by the RNA values.

Differences in experimental design between the 2 years and the interaction of year with other main effects required that a separate ANCOVA be conducted for each year. During 1994, the main effects of estuary, habitat nested in estuary, and experimental run nested in estuary, were significant with either instantaneous growth or RNA concentration as the dependent variable (Table 3). Based on the post-hoc pairwise comparison results, flounder from the Great Bay/Little Egg Harbor estuary had statistically higher growth rates and RNA concentrations than did fish from Hammonasset. Growth rates in Navesink were lower than expected based on the RNA concentration. Habitat differences showed similar patterns for RNA and instantaneous growth in $73 \%$ of the 30 post-hoc pairwise comparisons, and agreed statistically in $63 \%$ of them. Of the 8 pairwise comparisons which showed dissimilar patterns, 7 can be attributed to marsh creek comparisons in both Great Bay/Little Egg and Navesink, where growth was less than predicted by the RNA values. Overall, few habitats differed in growth rates within an estuary, with the exception of marsh creek. Lsmeans for RNA concentration and growth in Experimental Run 1 were greater than Experimental Run 2 in all of the estuaries and agreed statistically in 2 out of the 3 estuaries.

During 1995, the main effects of estuary and habitat nested in estuary were significant with either RNA concentration or instantaneous growth as the dependent variable (Table 3). Based on the post-hoc pairwise comparison results, fish from the Navesink estuary had statistically higher RNA concentrations and instantaneous growth rates than did fish from the Great Bay/Little Egg Harbor estuary. Growth rates in Hammonasset were lower than expected based on the RNA concentration. Habitat differences showed similar patterns for RNA and instantaneous growth in all 18 posthoc pairwise comparisons and agreed statistically in $89 \%$ of them.

Overall, RNA concentration and instantaneous growth rate showed similar patterns across the habi- 


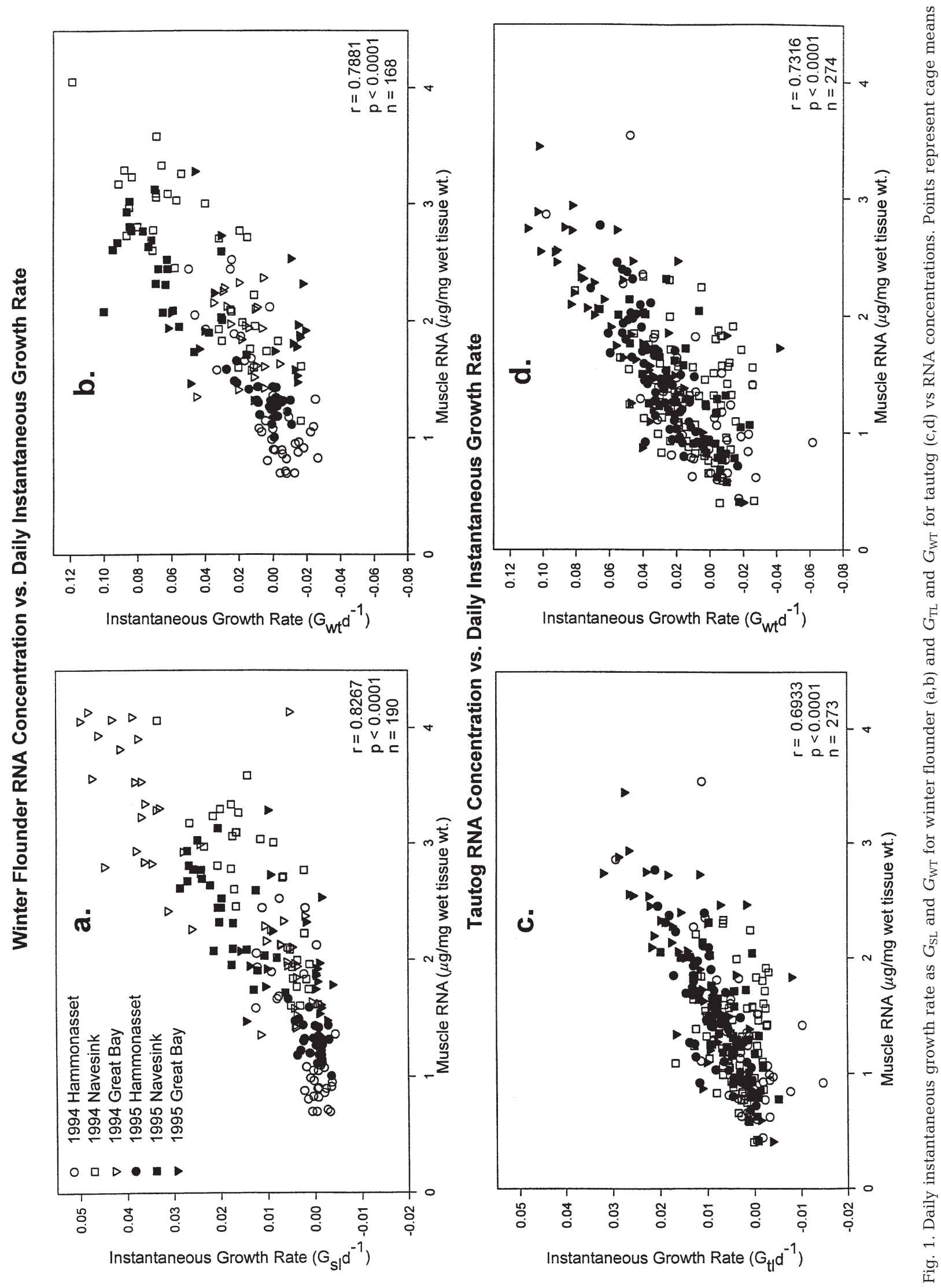


Table 3. Summary of probabilities $(\mathrm{p}>F$ ) from ANCOVAs, containing significant terms only, for winter flounder and tautog cage means during each study year. Dependent variables were daily instantaneous growth rate as length $\left(G_{\mathrm{SL}}\right)$ or weight $\left(G_{\mathrm{WT}}\right)$ and white muscle RNA concentration ( $\mu \mathrm{g}$ per mg wet tissue wt)

\begin{tabular}{|c|c|c|c|c|}
\hline & \multicolumn{2}{|c|}{1994} & \multicolumn{2}{|c|}{1995} \\
\hline & RNA & $G_{\mathrm{SL}}$ & RNA & $G_{\mathrm{SL}}$ \\
\hline \multicolumn{5}{|l|}{ Winter flounder } \\
\hline Estuary & 0.001 & 0.001 & 0.013 & 0.001 \\
\hline Habitat (estuary) & 0.009 & 0.018 & 0.001 & 0.001 \\
\hline Experimental run (estuary) & 0.001 & 0.001 & NA & NA \\
\hline Replicate (estuary habitat experimental run) & & 0.009 & & 0.001 \\
\hline Linear covariate (initial standard length) & 0.001 & 0.001 & 0.001 & \\
\hline Corrected total df & 116 & 116 & 73 & 73 \\
\hline \multirow[t]{2}{*}{$\mathrm{r}^{2}$} & 0.94 & 0.96 & 0.85 & 0.94 \\
\hline & RNA & $G_{\mathrm{WT}}$ & RNA & $G_{\mathrm{WT}}$ \\
\hline \multicolumn{5}{|l|}{ Tautog } \\
\hline Estuary & & & 0.001 & 0.001 \\
\hline Habitat (estuary) & 0.020 & 0.001 & 0.001 & 0.001 \\
\hline Experimental run (estuary) & 0.001 & 0.001 & 0.021 & 0.001 \\
\hline Habitat $\times$ Experimental run (estuary) & & 0.003 & 0.028 & 0.001 \\
\hline Linear covariate (initial weight) & & & 0.001 & 0.001 \\
\hline Corrected total df & 116 & 116 & 157 & 157 \\
\hline $\mathrm{r}^{2}$ & 0.57 & 0.57 & 0.67 & 0.73 \\
\hline
\end{tabular}

tats within the estuaries over the 2 yr of the study. In general, the smallest winter flounder tended to grow fastest, contain the highest RNA concentrations, and occur earliest in the year. For brevity, 1 example of the relationship between RNA concentration and instantaneous growth in winter flounder is illustrated in Fig. 2 $(\mathrm{a}, \mathrm{b}, \mathrm{c})$, which depicts the habitat results by estuary from 1994.

\section{Tautog}

The correlation between RNA concentration and instantaneous growth rate was highly significant $(\mathrm{p}<$ 0.0001 ) in tautog, as measured by both total length ( $\mathrm{r}=$ $0.69)$ and weight $(r=0.73)$, for both study years combined (Fig. 1c,d). The residuals from regressing RNA concentration on growth were randomly distributed when plotted against both RNA and initial weight.

As with winter flounder, separate ANCOVAs were conducted for each year. During 1994, the main effects of habitat nested in estuary, and experimental run nested in estuary, were significant with either RNA concentration or instantaneous growth as the dependent variable (Table 3). A significant interaction between habitat and experimental run indicated the effect of time on growth within habitats. Nevertheless, according to the post-hoc pairwise comparison results, habitat differences for all 3 experimental runs showed similar patterns for RNA and instantaneous growth in
$94 \%$ of the 52 pairwise comparisons, and agreed statistically in $81 \%$ of them. Experimental run differences for all 5 habitats showed similar patterns for RNA and instantaneous growth in $92 \%$ of the 26 pairwise comparisons, and agreed statistically in $73 \%$ of the cases.

During 1995 the main effects of estuary, habitat nested in estuary, and experimental run nested in estuary were significant with either RNA concentration or instantaneous growth as the dependent variable (Table 3). Based on the post-hoc pairwise comparisons results, tautog from the Great Bay/Little Egg Harbor and Hammonasset estuaries had statistically higher RNA concentrations and instantaneous growth rates than those from Navesink. According to the post-hoc pairwise comparison results, habitat differences for both experimental runs in 1995 showed similar patterns for RNA and instantaneous growth in $97 \%$ of the 36 pairwise comparisons, and agreed statistically in $83 \%$ of them. Experimental run differences for all 4 habitats showed similar patterns for RNA and instantaneous growth in $92 \%$ of the 26 pairwise comparisons, and agreed statistically $67 \%$ of the time.

RNA concentrations and instantaneous growth in tautog showed similar patterns across habitats within the estuaries over the 2 yr of the study. In general, the smallest tautog grew fastest, contained the highest RNA concentrations and occurred earliest in the year.

For brevity, 1 example of the relationship between RNA concentration and instantaneous growth in 


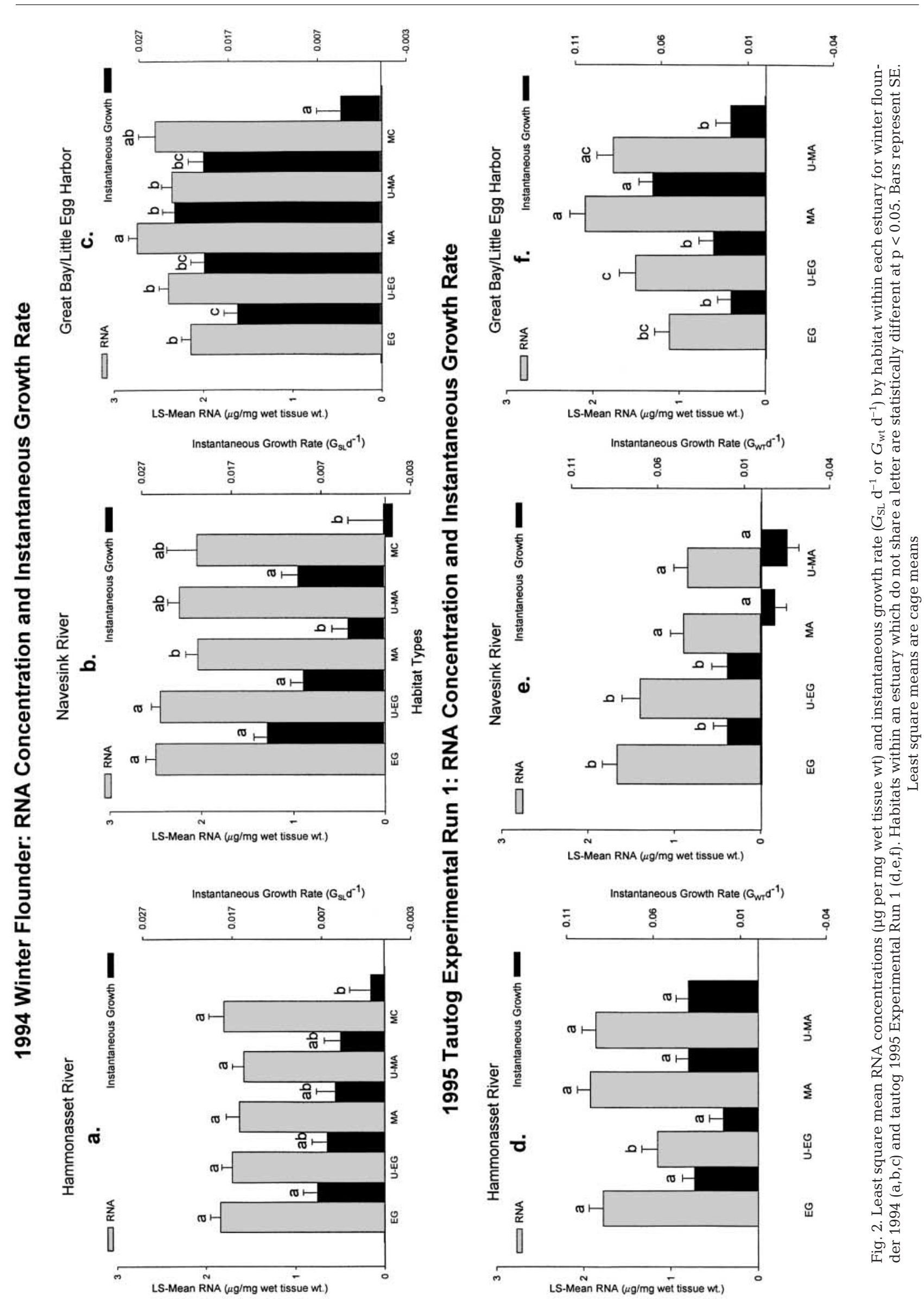


tautog is illustrated in Fig. 2 (d,e,f), which depicts the habitat results by estuary from 1995 Experimental Run 1.

\section{DISCUSSION}

Our study found a strong correlation between white muscle tissue RNA concentration and instantaneous growth rate for both young-of-the-year winter flounder and tautog. Other studies have also documented significant relationships between white muscle tissue RNA concentration and specific growth rate (wet wt) in many juvenile marine and freshwater fish species $\left(\mathrm{r}^{2}\right.$ range 0.58 to 0.93) (Goolish et al. 1984, Mathers et al. 1992, Foster et al. 1993, Wang et al. 1993, Arndt et al. 1994, Carter et al. 1998). Several of these studies suggest that RNA concentration reflects actual growth rate as well as or better than other nucleic acid measures including RNA/DNA or RNA/protein.

However, not all studies agree that RNA concentration is an accurate growth measure in juvenile fish. McLaughlin (1995a) found no difference in RNA concentration between fed and starved juvenile brook trout and concluded that RNA concentration and other nucleic acid measures are relative, rather than absolute, measures of nutritional status. In a related study, juvenile brook trout exhibited lagged responses in RNA concentration after exposure to fluctuations in food availability (McLaughlin et al. 1995b). In contrast, other studies suggest that nucleic acid measures respond quickly to changes in nutritional condition. For example, RNA concentrations in starved juvenile cod were found to recover within $5 \mathrm{~d}$ after the reintroduction of food (Foster et al. 1993). In laboratory experiments, Malloy \& Targett (1994a) observed RNA/DNA ratios in juvenile summer flounder to respond rapidly to changes in feeding regime, sometimes within $1 \mathrm{~d}$, and concluded that the high temporal resolution of nucleic acid techniques allow accurate estimates of short-term growth rates.

The overall strength of the relationship between RNA concentration and instantaneous growth as length was slightly better for winter flounder than tautog. This could be a species-specific difference in the RNA/growth relationship or, more likely, a difference in the accuracy of the instantaneous growth measurements among species. The flat morphology of the flounder lends itself better to accurate length measurements than does the fusiform tautog, with its nearly transparent tail.

In the present study, RNA concentration tracked somatic growth well for fish ranging in size from 20 to $46 \mathrm{~mm}$ SL for winter flounder and from 32 to $49 \mathrm{~mm} \mathrm{TL}$ for tautog (Fig. 1). Malloy \& Targett (1994a) found that the RNA/DNA ratio-growth rate relationship in summer flounder was unaffected by body weight for fish ranging in size from 18 to $80 \mathrm{~mm}$ TL. Stability in the growth relationship over a wide range of sizes is important, since the proportion of components other than RNA-producing muscle tissue begins to increase during the juvenile stage. This can result in large individuals with the same RNA/DNA ratio growing at a slower rate than smaller individuals (Buckley 1984). For this reason, RNA concentration or RNA/protein is thought to be a better indicator of growth than RNA/ DNA when comparing late-stage juvenile fish of varying size (Buckley et al. 1999).

The correlation scatter plots, which subdivide growth results by estuary and year, and Table 1, which lists mean size by experimental run, indicates a relationship between growth rate and fish size in winter flounder. The smallest fish, from Great Bay/Little Egg Harbor during the first experimental run of 1994, showed the fastest growth rates and highest RNA values, while the largest flounder, from Hammonasset during both years, experienced the slowest growth rates and lowest RNA values. A similar relationship between RNA concentration, growth rate, and fish size is also present in tautog. These results also show that growth rates of the smallest fish (winter flounder TL $<20 \mathrm{~mm}$ ) were higher than would be predicted from the RNA values. These positive residuals could be an anomaly due to difficulty in accurately measuring length of small fish, or could indicate a change in the RNA-growth relationship at this size.

Temperature is a significant factor for better defining the relationship between RNA concentration and juvenile fish growth. While RNA represents the cell's mechanism for protein synthesis, temperature controls the rate at which protein is synthesized (Fry 1971). Malloy \& Targett $(1994 \mathrm{a}, \mathrm{b})$ found that the inclusion of a temperature term improved the relationship between RNA/DNA ratio and growth rate in juvenile summer flounder from a Delaware estuary. In his work with carp, Goolish et al. (1984) found acclimation temperature to have a significant effect on the ratios of RNA:tissue and RNA/DNA. Buckley (1984) developed a general equation for larval marine fish that relates RNA/DNA ratios and temperature to growth rates. For a given RNA/DNA ratio, growth increased about $1 \%$ $\mathrm{d}^{-1}$ for every $1^{\circ} \mathrm{C}$ increase in water temperature. In a related study, winter flounder larvae were reared at 3 temperatures on a diet of wild plankton. RNA/DNA ratios alone explained $53 \%$ of the observed variability in growth, while temperature and RNA/DNA ratio together explained $72 \%$ of the variability (Buckley 1982). During the current study, RNA concentration explained $68 \%$ and $54 \%$ of the observed variability in juvenile winter flounder and tautog growth, respec- 
tively. The specific effects of temperature on the relationship between RNA concentration and growth of young-of-the year winter flounder and tautog are not well understood, and larval results may not hold true for older fish (Buckley et al. 1999). Differences in RNA concentration and growth rate between years within an estuary suggest that seasonal effects, such as temperature, may indeed be a confounding factor. Incomplete temperature profiles among the estuaries and habitats during this study preclude a further understanding of the impact of temperature on RNA concentration.

Using RNA concentration as an index of growth, growth rates were found to vary with year, estuary, habitat and experimental run. These conclusions were very similar to the findings of Phelan et al. (2000), although our data set was smaller, consisting of $64 \%$ and $42 \%$ of the total winter flounder cage means and $64 \%$ and $98 \%$ of the total tautog cage means for 1994 and 1995 respectively. Winter flounder RNA concentrations closely reflected growth measurements in all of the habitats, except marsh creek, where growth was much lower than predicted by the RNA values. These elevated RNA levels, relative to instantaneous growth, could reflect increased synthesis of proteins unrelated to growth, such as stress proteins. Fish in the marsh creek habitats in all 3 estuaries were exposed to some of the highest temperatures and lowest dissolved oxygen levels recorded and had the lowest recoveries ( $<20 \%$ for winter flounder and $<30 \%$ for tautog) (Phelan et al. 2000), indicative of a high mortality rate.

RNA concentration closely followed instantaneous growth in young-of-the-year tautog. Results agreed statistically in $80 \%$ of the post-hoc tests, while an additional $15 \%$ of the comparisons, although not statistically significant, showed similar trends. For a detailed discussion of the ecological implications of the estuary and habitat results, based on the complete data set of instantaneous growth rate measurements, see Phelan et al. (2000).

Laboratory trials using juvenile red drum Sciaenops ocellatus have established a strong relationship between RNA/DNA ratio and nutritional condition and have provided a framework for evaluating condition of that species in the wild (Rooker et al. 1996, 1997). The strong relationship between RNA concentrations and growth measurements observed during this study indicate that RNA analyses may be a valuable tool for assessment of field growth in young-of-the-year winter flounder and tautog. Measurement of RNA in fieldcaught animals from different habitats would provide essential growth information without the need for caging. Nucleic acid measurements are accurate at determining growth over short time intervals and during periods of slow growth, when changes in somatic measurements may be almost undetectable. Laboratory calibration studies of RNA concentrations and growth rates, at a variety of temperatures and feeding regimes, are needed to further define the relationship between temperature and RNA concentration and growth rate. These studies will allow better assessment of nutritional condition in field-caught fish and should allow the assignment of specific growth rates to wild flounder and tautog.

Acknowledgments. The authors thank Dr. Richard Trout for suggesting the statistical design, and Dr. Anthony Calabrese for editorial assistance. A special thanks to the field teams at the NOAA/NMFS Milford and James J. Howard Marine Sciences Laboratories and Rutgers University for conducting the field experiments and providing the fish. This study was funded through NOAA's Coastal Ocean Program.

\section{LITERATURE CITED}

Able KW (1999) Measures of juvenile fish habitat quality: examples from a National Estuarine Research Reserve. In: Benaka LR (ed) Fish habitat: essential fish habitat and rehabilitation. Amer Fish Soc Sym 22, Bethesda, MD, p 134-147

Arndt SKA, Benfey TJ, Cunjak RA (1994) A comparison of RNA concentrations and ornithine decarboxylase activity in Atlantic salmon (Salmo salar) muscle tissue, with respect to specific growth rates and diel variations. Fish Physiol Biochem 13(6):463-471

Balstrop R, Spangenberg R, Jurss K (1991) Biochemical adaptation of juvenile carp (Cyprinus carpio L.) to food deprivation. Comp Biochem Physiol 98A:143-149

Buckley LJ (1982) Effects of temperature on growth and biochemical composition of larval winter flounder Pseudopleuronectes americanus. Mar Ecol Prog Ser 8:181-186

Buckley LJ (1984) RNA-DNA ratio: an index of larval fish growth in the sea. Mar Biol 80:291-298

Buckley LJ, Bulow FJ (1987) Techniques for the estimation of RNA, DNA, and protein in fish. In: Summerfelt RC, Hall GE (eds) Age and growth of fish. The Iowa State University Press, Ames, IA, p 345-354

Buckley LJ, Caldarone EM (1988) Recent growth and biochemical composition of juvenile, young-of-year winter flounder from different areas of Narragansett Bay. Final report to the Narragansett Bay Project

Buckley L, Caldarone E, Ong TL (1999) RNA-DNA ratio and other nucleic acid-based indicators for growth and condition of marine fishes. Hydrobiologia 401:265-277

Bulow FJ (1987) RNA-DNA ratios as indicators of growth in fish: a review. In: Summerfelt RC, Hall GE (eds) Age and growth of fish. The Iowa State University Press, Ames, IA, p 45-64

Carter CG, Seeto GS, Smart A, Clarke S, van Barneveld RJ (1998) Correlates of growth in farmed juvenile southern bluefin tuna Thunnus maccoyii (Castelnau). Aquaculture 161:107-119

Foster AR, Houlihan DF, Hall SJ (1993) Effects of nutritional regime on correlates of growth rate in juvenile Atlantic cod (Gadus morhua): comparisons of morphological and biochemical measurements. Can J Fish Aquat Sci 50: $502-512$

Fry FEJ (1971) The effects of environmental factors on the physiology of fish. In: Hoar WS, Randall DJ (eds) Fish 
physiology. Vol VI. Academic Press, New York, p 1-98

Goldberg R, Studholme A, Calabrese A, Able K (1993) Functional significance of estuaries in the northeast: a proposed case study comparing habitat utilization and quality. In: Magoon OT, Wilson WS, Converse H, Tobin LT (eds) Proceedings 8th Symposium on Coastal and Ocean Management. ASCE, 0-87262-918-x, New York, p 1630-1644

Goldberg R, Phelan B, Pereira J, Hagan S and 5 others (in press) Variability in habitat use by young-of-the-year winter flounder, Pseudopleuronectes americanus, across habitat-types in three northeastern US estuaries. Estuaries

Goolish EM, Barron MG, Adelman IR (1984) Thermoacclimatory response of nucleic acid and protein content of carp muscle tissue: influence of growth rate and relationship to glycine uptake by scales. Can J Zool 62:2164-2170

Malloy KD, Targett TE (1994a) The use of RNA:DNA ratios to predict growth limitation of juvenile summer flounder (Paralichthys dentatus) from Delaware and North Carolina estuaries. Mar Biol 118:367-375

Malloy KD, Targett TE (1994b) Effects of ration limitation and low temperature on growth, biochemical condition, and survival of juvenile summer flounder (Paralichthys dentatus) from two Atlantic coast nurseries. Trans Am Fish Soc 123:182-193

Mathers EM, Houlihan DF, Cunningham MJ (1992) Nucleic acid concentrations and enzyme activities as correlates of growth rate of the saithe Pollachius virens: growth-rate estimates of open-sea fish. Mar Biol 112:363-369

Mathers EM, Houlihan DF, McCarthy ID, Burren LJ (1993) Rates of growth and protein synthesis correlated with nucleic acid content in fry of rainbow trout, Oncorhynchus mykiss: effects of age and temperature. J Fish Biol 43: 245-263

Editorial responsibility: Kenneth Sherman (Contributing Editor), Narragansett, Rhode Island, USA
McLaughlin, RL, Ferguson MM, Noakes DLG (1995a) Tissue concentrations of RNA and protein for juvenile brook trout (Salvelinus fontinalis): lagged responses to fluctuations in food availability. Fish Physiol Biochem 14(6): 459-469

McLaughlin, RL, Ferguson MM, Noakes DLG (1995b) Concentrations of nucleic acids and protein as indices of nutritional status for recently emerged brook trout (Salvelinus fontinalis). Can J Fish Aquat Sci 52:848-854

Phelan BA, Goldberg R, Bejda AJ, Pereira J, Hagan S, Clark P, Studholme AL, Calabrese A, Able KW (2000) Estuarine and habitat-related differences in growth rates of youngof-the-year winter flounder (Pseudopleuronectes americanus) and tautog (Tautoga onitis) in three northeastern US estuaries. J Exp Mar Biol Ecol 247(1):1-28

Rooker JR, Holt GJ (1996) Application of RNA:DNA ratios to evaluate the condition and growth of larval and juvenile red drum (Sciaenops ocellatus). Mar Freshw Res 47: $283-290$

Rooker JR, Holt GJ, Holt SA (1997) Condition of larval and juvenile red drum (Sciaenops ocellatus) from estuarine nursery habitats. Mar Biol 127:387-394

Sogard SM (1992) Variability in growth rates of juvenile fishes in different estuarine habitats. Mar Ecol Prog Ser 85: $35-53$

Varnavskiy VS, Varnavskaya NV, Kalinin SV, Kinas NM (1991) RNA/DNA index as an indicator of growth rate of coho salmon (Oncorhynchus kisutch) during early marine life. Vop Ikhtiol 31 (5):783-789

Wang, SY, Lum JL, Carls MG, Rice SD (1993) Relationship between growth and total nucleic acids in juvenile pink salmon, Oncorhynchus gorbuscha, fed crude oil contaminated food. Can J Fish Aquat Sci 50:996-1001

Submitted: November 9, 1999; Accepted: July 2, 2001 Proofs received from author(s): March 8, 2002 